\title{
Perception of Noise Pollution in a Youth and Adults School in Curitiba-PR
}

\author{
Orlando Borges Filho ${ }^{1}$ Angela Ribas ${ }^{1}$ Claudia Giglio De Oliveira Gonçalves ${ }^{1}$ \\ Adriana Bender Moreira Lacerda ${ }^{1}$ Renato Riesemberg ${ }^{1}$ Karlin Klagenberg ${ }^{1}$
}

${ }^{1}$ Department of Speech Therapy, Universidade Tuiuti do Parana, Curitiba, PR, Brazil

Int Arch Otorhinolaryngol 2017;21:313-317.
Address for correspondence Angela Ribas, MD, Universidade Tuiuti do Paraná - Programa de Mestrado e Doutorado em Distúrbios da Comunicação da Universdidade Tuiuti do Paraná, Rua Jose Isidoro Biazetto 845, Curitiba, PR 81200240, Brazil (e-mail: angela.ribas@utp.br).

\begin{abstract}
Keywords

- perception

- noise

- schools

- environmental pollution

Introduction Nowadays noise remains the third largest cause of environmental pollution on Earth. It appears that despite the existing noise control legislation the issue deserves further supervision by the public authorities so that the ceilings established for the various activities are observed. People exposed to noise are more likely to develop numerous auditory and non-auditory problems directly impacting persona family and working life.

Objectives The objective of this study is to research and consequently understand how the population of students of a youth and adult school in Curitiba perceives noise pollution as well as look into the actions that the school adopts in order to guide the students on the topic.

Method We applied a structured questionnaire to 120 individuals and assessed the following variables: characterization of the place of residence occupation leisure health and perception of soundscapes. We also applied a closed questionnaire about educational actions for noise pollution to the school's geography teacher.

Results Questionnaire responses show that people perceive noise in the most diverse environments they frequent and are able to identify the source of the noise but this perception proved fragile as the majority does not take measures to prevent or mitigate these noises. At school there are no actions aimed at environmental education on the subject studied.

Conclusion The studied group does not perceive the noise as a harmful agent and does not prevent themselves from it and the school not work contents related to noise pollution leaving a significant gap in the awareness process of this population.
\end{abstract}

\section{Introduction}

Loud sounds, known as noise, are present in a variety of activities and environments that people experience, with much being said about the damage noise causes to the human being in current research. ${ }^{1-5}$

Indeed, noise is a trademark of modern society ${ }^{6}$ and people are generally aware of it, but why is so difficult to change their attitude toward this reality?

received

June 7, 2016

accepted

October 6, 2016

published online

December 19, 2016
Research shows that people are aware of the fact that noise is harmful, but fail to avoid exposure to it, whether in leisure, ${ }^{7,8}$ occupational, ${ }^{9,10}$ or study environments, ${ }^{11,12}$ and even in homes. ${ }^{13}$

According to Floriani, ${ }^{14}$ knowing and appreciating is essential for people to realize the need for a change in their surroundings. Particularly with regards to knowledge, Ribas ${ }^{15}$ says that people must reach levels of emotional insight ${ }^{16}$ so that their behavior can change facing an imposed reality.
Copyright $\odot 2017$ by Thieme Revinter

Publicações Ltda, Rio de Janeiro, Brazil
License terms

(이 (1) $\Theta \circledast$ 10.1055/s-0036-1597118. ISSN 1809-9777. 
Different specialties from distinct sectors of society have studied noise pollution, the third cause of the planet's pollution, as well as its harmful effects. ${ }^{17}$ Researchers believe that the key to improving knowledge and intensifying protective and preventive actions against noisy environments falls under the scope of the field of Environmental Education. ${ }^{11,18}$

Environmental Education refers to processes through which the individual and society as a whole build social principles, knowledge, skills, attitudes, and competencies directed toward environmental conservation, an important asset for a community's well-being and its sustainable development. ${ }^{19}$

Environmental Education belongs to the field of Geography, which investigates the causes, effects, and prevention methods of noise pollution. Some studies stress the pressing need for investment in this field, to devise specific strategies that would help guide individuals in choosing or adapting their environment. ${ }^{20}$

Environmental Education is an intentional social practice, which should instill in individuals development a social character in their relationship with nature and with other human beings. The aim is to strengthening this human activity interacting the social and environmental practice. ${ }^{21}$

This research is justified given the limited number of Brazilian studies available on the perception of noise among students from Youth and Adult Education schools (YAE), within an Environmental Education approach. The YAE typically caters to students that are formally or informally employed in commerce, services, industries, as well as stay-at-home workers, unemployed, or retirees. These students return to school outside the standard chronological timeline with an interest in getting hired, better jobs, promotions, and entering new markets. The minimum age to join the YAE is 15 years old for elementary and 18 for secondary education, with no maximum age limit. The system offers grades 5 to 8 of Basic Education and complete High School. ${ }^{22}$ The Brazilian Government officially informs the community that this type of education is available in the State Center for Basic Education for Youth and Adults in State Schools, prison units, and in learning centers, and Decentralized Pedagogical Actions. ${ }^{21}$

Given this context, our research had the following goals: a) to acquire a greater understanding of how the population of students of a Youth and Adult School in Curitiba perceives noise pollution; b) check the actions that the school adopts to guide the students on the topic.

The results of this study sheds light on the importance of educating youth and adults on issues related to noise pollution. In this sense, the YAE schools environment is conducive to the development of projects in this field. In addition to critically building their own foundations, preventing noise exposure, and avoiding its sequelae, the students become diffusers of such learning with their actions and knowledge in the immediate environment in which they live. Reaching people who are around them, the students start to multiply knowledge and share the various existing forms of intervention aimed at prevention and environmental comfort.

\section{Materials and Methods}

This is an exploratory research, of descriptive character, held in March 2015. This study is part of the research project titled "Reflections on the sound environment quality in the city of Curitiba," approved by the Institutional Ethics Committee under number CEP/UTP 017/2006.

The study included 120 adult volunteers, randomly selected in a YAE school in Curitiba and a Geography teacher. All signed the Free and Clarified Consent Form.

The study sample consisted of students who were attending classes in 2015 and had conditions to read and interpret the data collection protocol. We excluded from the sample students who did not understand the research terms.

We applied to all the participants a semi-structured ${ }^{15}$ questionnaire consisting of two parts, which investigated the following variables:

Part 1: characterization of the sample by age, gender, education, place of residence, and identification of negative points in the home region.

Part 2: characterization of work and leisure activities; health aspects in general; perception of noise in the environment they frequent.

We did not declare the objective of the research (to investigate the perception of noise) so as not to influence the respondents in the first part of the questionnaire, which sought to spontaneously identify noise as a harmful agent. Only after the completion of the first part did the students receive the second. We tabulated and qualitatively analyzed the answers to each question.

We also applied a structured questionnaire to the school geography teacher on educational activities focused on the issue of noise pollution, with answer choices being YES, NO, and I DO NOT KNOW.

\section{Results}

The sample was characterized by homogeneous regarding sex: $49 \%$ of women and $51 \%$ men. The mean age was 32.2 years, and the youngest respondent was 18 and the oldest was 57 . The majority of respondents live in the outskirts of Curitiba (89\%), in a house (72\%), in a masonry house (77\%).

When asked about the negative points observed in the region where they live, they indicated: violence (50\%), infrastructure $(22 \%)$, noise $(20 \%)$, vehicle traffic $(12 \%)$, public cleaning (11\%), and other less relevant aspects.

The majority of the respondents is active from the occupational point of view and receives between one and three minimum wages per month (78\%). They work in trade (45\%) and industry (33\%).

When asked about leisure activities, most (79\%) referred practicing them often and 53\% said that during this practice, there is often noise in environments such as gyms, bars, soccer stadium, church, among others.

Health problems were reported by $20 \%$ of respondents, and the signs and symptoms are shown in - Table 1, but no respondents associated the complaint to exposure to noise, 
Table 1 Characterization of the sample according to reported signs and symptoms $(N=120)$

\begin{tabular}{|l|l|l|}
\hline Symptoms & N & $\%$ \\
\hline Anxiety & 54 & 45 \\
\hline Stress & 33 & 27.5 \\
\hline Nervousness & 27 & 22.5 \\
\hline Vision problems & 27 & 22.5 \\
\hline Irritability & 22 & 18 \\
\hline Fatigue & 19 & 16 \\
\hline Headache & 16 & 13 \\
\hline Tinnitus & 10 & 8 \\
\hline Gastric problems & 7 & 6 \\
\hline Hearing Loss & 3 & 2.5 \\
\hline Sleep disorders & 4 & 3 \\
\hline Difficulty understanding speech & 3 & 2.5 \\
\hline
\end{tabular}

even those who work in noisy places (industrial workers). Regarding the perception that these subjects have about the noise, the data are recorded in - Table 2, and the teacher's responses are presented in - Table 3 .

\section{Discussion}

According to the World Health Organization, ${ }^{23}$ it is difficult to measure the noise impact on the quality of life because the factors are diverse. Nevertheless, the entity claims there is a need to study noise as this situation involves the world population at a large scale.

Exemplifying what happens to other populations also investigated about the perception of noise pollution, 1,15 students who participated in this study have demonstrated little knowledge on the subject. Before being sensitized on the subject of the research, only $20 \%$ of the sample identified noise as a negative factor present in environments they frequent, and this perception has been supplanted by the sense of insecurity (50\%) and infrastructure (22\%). Those who state that noise is harmful to health are contradictory when exposed to loud sounds in leisure activities or producing noise without caring about neighbors, for example.

A justification for this behavior can be the average age of the sample and low education. The sample average age is relatively young (32 years). It is known that the loud sound associated with physical activity releases adrenaline, which generates pleasure, ${ }^{24}$ and often there lies the justification for children, adolescents, and young adults to expose themselves to amplified music and other noises in their day-to-day activities. ${ }^{25}$ As for education, studies say that the lower the education, the lower the capacity of reality perception. The students of the YAE are largely people who chronologically returned to study outside the conventional timeframe.

As noise and hearing loss do not appear, they are invisible to the eye, several times it is not perceived as something negative. ${ }^{26,27}$ However, noise does not appear, it is invisible to
Table 2 Noise perception among respondents

\begin{tabular}{|c|c|c|}
\hline Questions & $\mathbf{N}$ & $\%$ \\
\hline \multicolumn{3}{|c|}{ How is the noise in the area where you live? } \\
\hline Low intensity & 54 & 45 \\
\hline Moderate & 57 & 47.5 \\
\hline Intense & 9 & 7.5 \\
\hline \multicolumn{3}{|c|}{ What are the sources of noise where you live? } \\
\hline Vehicle traffic & 27 & 22 \\
\hline Neighborśs music & 77 & 62 \\
\hline Other & 19 & 16 \\
\hline \multicolumn{3}{|c|}{ Does noise prevent you from performing tasks at home? } \\
\hline Yes & 36 & 30 \\
\hline No & 84 & 70 \\
\hline \multicolumn{3}{|c|}{ Do you do anything to avoid noise at home? } \\
\hline Yes & 66 & 55 \\
\hline No & 54 & 45 \\
\hline \multicolumn{3}{|c|}{ Do you make noise capable of disturbing your neighbors? } \\
\hline Yes & 30 & 25 \\
\hline No & 90 & 75 \\
\hline \multicolumn{3}{|c|}{ Do you do something to mitigate this noise? } \\
\hline Yes & 30 & 25 \\
\hline No & 90 & 75 \\
\hline \multicolumn{3}{|c|}{ Would you change residence because of noise? } \\
\hline Yes & 24 & 20 \\
\hline No & 96 & 80 \\
\hline \multicolumn{3}{|c|}{ Do you think that noise can cause damage to health? } \\
\hline Yes & 36 & 30 \\
\hline No & 75 & 62.5 \\
\hline \multicolumn{3}{|c|}{ Do you know of any harm caused by noise? } \\
\hline Yes & 36 & 30 \\
\hline No & 84 & 70 \\
\hline \multicolumn{3}{|c|}{ Do you prevent harm from hearing noise? } \\
\hline Yes & 48 & 40 \\
\hline No & 72 & 60 \\
\hline
\end{tabular}

the eye, and the main sequel, hearing loss, is invisible too. Unlike, for instance, other types of pollution (water and air) or other symptoms (cough, allergy, diarrhea, among others, caused by pollution of air and water).

In our study we found that $20 \%$ of respondents complained of health problems and many identified symptoms that could be related to exposure to loud sounds, such as anxiety, stress, nervousness, irritability, and fatigue. Some even mentioned hearing symptoms such as tinnitus, hearing loss, and difficulty understanding speech, but none associated the symptoms to exposure. Nevertheless, the number of respondents who are unaware of the effects of noise (70\%) and do not protect themselves from it (72\%) was elevated, even among those who 
Table 3 Educational activities focused on the issue of noise pollution in the researched school

\begin{tabular}{|l|l|}
\hline Question & Answers \\
\hline $\begin{array}{l}\text { Is Environmental Education addressed in the } \\
\text { school curriculum? }\end{array}$ & YES \\
\hline Is it included in the subject of Geography? & YES \\
\hline How about in other disciplines? & YES \\
\hline $\begin{array}{l}\text { In this subject, is the topic noise pollution } \\
\text { routinely addressed? }\end{array}$ & YES \\
\hline Are the students interested in this topic? & NO \\
\hline $\begin{array}{l}\text { Do the students raise the issue } \\
\text { in the classroom? }\end{array}$ & NO \\
\hline Is the teacher interested in the topic? & YES \\
\hline $\begin{array}{l}\text { Does the teacher approach the subject in } \\
\text { his or her classes? }\end{array}$ & YES \\
\hline $\begin{array}{l}\text { Is there sufficient time to address the issue } \\
\text { in the subject? }\end{array}$ & YES \\
\hline $\begin{array}{l}\text { Does the school carry out actions aimed at } \\
\text { the prevention of noise? }\end{array}$ & NO \\
\hline $\begin{array}{l}\text { Have you participated in any educational } \\
\text { campaign on noise? }\end{array}$ & NO \\
\hline $\begin{array}{l}\text { Was the topic addressed in your } \\
\text { teacher training? }\end{array}$ & NO \\
\hline $\begin{array}{l}\text { Does the community where the school } \\
\text { is inserted have an interest in this topic? }\end{array}$ \\
\hline
\end{tabular}

work in industry (33\%) and formally receive guidance on the subject. In any case, if we do not create expectations of a certain event, it will hardly be valued as important. Floriani ${ }^{14}$ affirms that ecological problems only become a matter of concern when they impose significant harm to human beings and nature. The data in -Table 2 reinforce the information that the sample studied does not value and, therefore, does not adequately perceive noise. Most participants state that noise does not bother them, does not interfere with performance of tasks, and do not recognize themselves as producers of noise. The population exposed to urban noise, even though aware of its presence, has no awareness of the effects that it can cause, which hinders initiatives being taken aimed at minimizing these effects. ${ }^{13}$

It is also necessary to think that it is common the sense of resignation and impotence before issues and situations involving modernity, among them noise pollution. After all, noise is an inherent part of the evolution of societies after the advent of the industrial revolution. ${ }^{28}$

According to Ribas, Nazareno, and Schmid, ${ }^{13}$ the population must become aware of noise and act to seek solutions, whether in the public or private sphere, changing habits and attitudes, including inside their own home. In this context, Environmental Education inserted in schools in general, would be the ideal location for the development of these skills.

Studies conducted in Brazil and around the world show that strategies to change concepts and, consequently, change behaviors pervade the channel of Environmental Education, ${ }^{18,29}$ a subject present in the basic curriculum. In our research, the teacher's report showed that the subject appears in the school program and noise is a topic of discussion in class out of his own initiative, but the school and the students are uninterested. This lack of interest, disregarding the negative connotation of the term, may be more a reflection of the superficiality with which the issue is addressed. In general, it is necessary to form a health consciousness awakening among the public to the subject, so that not only the individual is attentive towards the problem, but it faced collectively in a serious manner. ${ }^{13}$

In this sense, Geography can contribute significantly, as it studies the set of natural and human phenomena, which are aspects of the Earth's surface, considered in their distribution and mutual relations. When the interviewed teacher ( - Table 3 ) states that he includes noise as a topic in the discipline that he teaches, it becomes, even if modestly, a means of spreading knowledge.

Noise does not show its effects at first, but long-term consequences of exposure is detrimental to the individual because hearing loss deprives human beings of communication and contact with others, leading to isolation and social alienation. Avoiding exposure to loud sounds is the best way to prevent the development of hearing loss and other symptoms (tinnitus, difficulty understanding speech, irritability, fatigue, among others).

Finally, we must consider the physical and historical space occupied by a YAE school. The set of actors involved in this space, mainly adult learners able to replicate knowledge and make a difference in society, should be utilized. Finally, according to Braga, ${ }^{30}$ we must consider the physical and historical space occupied by a YAE school. The set of actors involved in this space, mainly adult learners able to replicate knowledge and make a difference in society, should be utilized.

\section{Conclusion}

Our study, of exploratory character and qualitative analysis, led us to the following considerations.

We were able to verify that the study group, formed by young people and adults, does not perceive noise as a harmful agent to the health of humans and, consequently, there is no prevention. This reality, based on other Brazilian and even international publications, reflects the way society as a whole deals with the issues of noise pollution.

Our results indicate that the population investigated does not demonstrate knowledge of existing measures to minimize the effects of noise. Finally, the study showed that the school investigated, destined for young and adult education, despite providing an environment that could enable the development of this knowledge, takes minimal action on the content, leaving a major gap in the awareness process of the student body towards the subject.

\section{References}

1 Silva DRC, Santos LM, Lemos SMA, Carvalho ASS, Perin RM. Conhecimentos e práticas de professores de educação infantil sobre crianças com alterações auditivas. J Soc Bras Fonoaudiol 2010;15(2):199-205 
2 Lacerda A, Figueiredo G, Massarolo JN, Marques JM. Achados audiológicos e queixas relacionadas à audição dos motoristas de ônibus urbano. J Soc Bras Fonoaudiol 2010;15(2):161-166

3 Fontoura FP. Trabalho, ruído e saúde dos profissionais de uma lavanderia hospitalar. [Dissertation]. Curitiba: UTP; 2011

4 Costa MM, Moreira SF, Souza M, Lima KR. Análise do nível de sonoridade em uma escola pública da cidade de Parnaíba-PI. [Anais] Sanare. 2015;14(1):132

5 Gonçalves CL. DIAS FAM. Achados audiológicos em jovens usuários de fones de ouvido. Rev. CEFAC. 2014;16(4):1097-1108

6 Ribas A, Graeml K. Poluição sonora: objeto de estudo da ecologia? Fonoaudiologia Brasil. 2006;4(1):16-22

7 Lacerda ABM, Gonçalves CGO, Zocoli AMF, Diaz C, Paula K. Hábitos auditivos e comportamento de adolescentes diante das atividades de lazer ruidosas. Rev. CEFAC. 2011;13(2):322-329

8 Lima FR. Silva NM. Ruídos da fé: estratégias para redução dos aspectos ambientais responsáveis pela poluição sonora de uma igreja evangélica em Natal/RN. Holos. 2009;3(1):162-179

9 Marques FP, Costa EA. Exposição ao ruído ocupacional: alterações no exame de emissões otoacústicas. Rev Bras Otorrinolaringol (Engl Ed) 2006;72(3):362-366

10 Palma A, Mattos UA, Almeida MN, Oliveira GE. Level of noise at the workplace environment among physical education teachers in indoor bike classes. Rev Saude Publica 2009;43(2):345-351

11 Jaroszewski GC, Zeigelboim BS, Lacerda ABM. Influence of school noise on dictation activity. Rev. CEFAC. 2007;9(1):122-132

12 Lacerda AB, Gonçalves CG, Lacerda G, et al. Childhood hearing health: educating for prevention of hearing loss. Int Arch Otorhinolaryngol 2015;19(1):16-21

13 Ribas A, Schmid A, Ronconi E. A percepção do ruído urbano e seus efeitos sobre a qualidade de vida de moradores dos setores especiais estruturais de Curitiba. Rev Geografias. 2010;10(1):70-86

14 Floriani D. Conhecimento, meio ambiente e globalização. Curitiba: Juruá; 2004

15 Ribas A. Reflexões sobre o ambiente sonoro da cidade de Curitiba: a percepção do ruído urbano e seus efeitos sobre a qualidade de vida de moradores dos Setores Especiais Estruturais [Tese]. Curitiba: UFPR; 2007

16 Kaplan HI, Sadock BJ, Greeb J. Compêndio de psiquiatria: ciências do comportamento e psiquiatria clínica. Porto Alegre: Artes Médicas; 1997
17 BORGES-FILHO. Orlando. Conscientização acerca da poluição sonora: relato de caso de uma escola de educação de jovens e adultos em Curitiba [Dissertação]. Curitiba: UTP; 2016

18 Moreira AC, Gonçalves CGO. A eficiência de oficinas em ações educativas na saúde auditiva realizadas com trabalhadores expostos ao ruído. Rev. CEFAC. 2014;16(3):723-731

19 BRASILLei n ${ }^{\circ}$ 9795/99. Dispõe sobre a Educação Ambiental, Institui a Política Nacional de Educação Ambiental e dá outras providências. Brasília: Casa Civil; 1999

20 Mello RA, Nogueira VCF, Pimentel RL. Avaliação do nível de ruído produzido pelo tráfego de veículos em sala de aula numa Universidade Pública. VI Encontro Nacional e IV Encontro Latino-americano sobre Edificações e Comunidades Sustentáveis; 2011

21 BRASIL. Resolução n 02/12, Título I, Capítulo I, Art. $2^{\circ}$. Estabelece as Diretrizes Curriculares Nacionais para a Educação Ambiental. Brasília: Ministério da Educação-Conselho Nacional de Educação; 2012

22 BRASIL. Lei n 9394/96. Dispõe sobre a Lei de Diretrizes e Bases da Educação Nacional. Brasília: Casa Civil; 1996

23 OMS. Critères d'hygiène de l'environnement. Genève: Organization Mondiale de la Santé; 1980

24 Pimentel-Souza F. Efeitos do ruído estressante. Anais da $49^{a}$ Reunião Anual da SBPC, Belo Horizonte: UFMG; 1997

25 Silvestre RA, Ribas A, Marques JM, Lacerda AB; SILVESTRI RAA. Tinnitus in adolescents and its relation to the use of personal sound systems. Int Tinnitus J 2013;18(2):138-142

26 Heemann A, Heemann N. Natureza e percepção de valores. Rev. Desenvolvimento e Meio Ambiente. 2003;7(1):32-35

27 Goldblat D. Teoria Social e Ambiente. Lisboa: Instituto Piaget; 1996

28 Gonzales CAG, Gonçalves CGO, Ribas A, Guida HL. O conhecimento e a percepção de supervisores de produção de uma indústria automobilística situada na Região Metropolitana de Curitiba sobre a saúde auditiva no trabalho. Rev Conhecimento Interativo. 2015; $9(1): 50-61$

29 Lacerda ABM, Soares VM, Gonçalves CGO, Lopes FC, Testoni R. Oficinas educativas como estratégia de promoção da saúde auditiva do adolescente: estudo exploratório. Audiol Commun Rev. 2013;18(2):85-92

30 Braga RM. O espaço geográfico: um esforço de definição. GEOUSPEspaço e Tempo 2007;22(1):65-72 